\title{
REVISIONES
}

\section{The hidden role of woody debris stocks as a woodfuel source: why cutting down trees if woodfuel can be gathered from forest floor?}

\author{
El papel subrepticio de los desechos leñosos como fuente de leña: \\ ¿Por qué talar árboles si la leña puede ser recolectada del suelo del bosque?
}

\author{
Javier Aristizábal
}

Fundación Natura, Subdirección de Desarrollo Local y Cambio Global Bogotá, Colombia, Carrera 21 No.39-43, jaristizabal@natura.org.co

\begin{abstract}
SUMMARY
Recently, the key role played by woody debris within the ecological dynamics of forest ecosystems has been acknowledged; however, its contribution as a source of woodfuel has barely been studied, despite being the most important energy resource for one-third of world population. Over decades, the widely held belief that woodfuel exclusively comes from woody living biomass has labelled woodfuel collection as a driver of tropical deforestation. The poor understanding about gathering ways of this resource in the rural developing world has hidden the fact that it is mainly sourced from woody necromass, of which their stocks and productivity may be estimated at $35 \mathrm{Pg}$ and $6.5 \mathrm{Pg}_{\text {year }}{ }^{-1}$ in tropical forests, respectively. Whether necromass productivity of both geographically accessible tropical forest for rural communities and other types of woody vegetation is taken into account together, a potential supply of $2.19 \mathrm{Pg}$ year ${ }^{-1}$ could be estimated, which would meet by far, the projected global rural woodfuel demand. It concludes that household-oriented woodfuel collection is far from being a driver of deforestation; instead, this latter might jeopardize access to this energy source. This paper tries to provide a new insight about the relationship between rural energy security and forest-based ecosystem services and their repercussions on climate change.
\end{abstract}

Key words: necromass, deforestation, cookstoves, non-renewable biomass.

\section{RESUMEN}

Recientemente, se ha reconocido el papel fundamental que desempeñan los residuos leñosos dentro de la dinámica ecológica de los ecosistemas forestales, sin embargo, poco se ha estudiado respecto a su contribución como fuente de un recurso energético tan importante como la leña de la cual dependen más de una tercera parte de la población mundial. Durante décadas ha persistido la creencia generalizada que la leña procede exclusivamente de las reservas de la biomasa en pie, por lo cual, su recolección ha sido calificada como una actividad promotora de la deforestación tropical. La pobre comprensión que existe sobre las formas de apropiación de este recurso en el medio rural de países en vías de desarrollo ha ocultado el hecho que su principal fuente procede de la necromasa leñosa cuyas reservas y productividad pueden estimarse en alrededor de $35 \mathrm{Pg}$ y $6,5 \mathrm{Pg}$ año-1 para los bosques tropicales, respectivamente. Considerando la productividad de la necromasa tanto de áreas forestales tropicales físicamente accesibles para las poblaciones rurales como de otros tipos de vegetación leñosa, se estima una oferta potencial de 2,19 $\mathrm{Pg} \mathrm{año}^{-1}$, la cual puede satisfacer la demanda global de leña. Se concluye que la recolección de leña para cocción doméstica está lejos de ser un agente causal de la deforestación y que por el contrario, la deforestación podría poner en peligro el acceso a esta forma de energía. Este artículo intenta proveer una nueva perspectiva de la relación entre la seguridad energética rural y los servicios ecosistémicos ofrecidos por los bosques y cómo ambos repercuten en el cambio climático.

Palabras clave: necromasa, deforestación, estufas, biomasa no renovable.

\section{INTRODUCTION}

Forest ecosystems provide several goods and services, from which woodfuel supply is the most important for one-third of the world population relying on traditional biomass for meeting their needs for cooking and heating.
The widespread belief about household-oriented woodfuel collection as a driver of tropical deforestation has been held for decades (Eckholm 1975). However, this view only reveals the poor understanding existing about woodfuel gathering ways by rural communities; moreover, it proves how lack of awareness about forests regrowth 
and mortality has been overlooking its ability as a woodfuel source.

Estimates about supply ability of forests have just been focused on assessing the fraction of woodfuel from living aboveground biomass stocks as the most predominant component in such ecosystems. Nonetheless, woodfuel sourced from woody debris stocks has not yet been considered. Data collected by several surveys show woody debris stocks may account for $1-27 \%$ of total forest biomass (both living aboveground biomass and necromass together) in undisturbed forests and more than $70 \%$ in heavy-logged forests (Palace et al. 2012, Pfeifer et al. 2015).

By 2010, global deadwood stocks had been estimated at about $67 \mathrm{Pg}$; whereas aboveground biomass stocks went up $600 \mathrm{Pg}$ (FAO 2010). When added together, deadwood would account for $10 \%$ of total woody biomass stocks from world forests.

This figure should not be disregarded since woody debris represents the most relevant type of woodfuel collected by users because of its availability in forests and other woodlands, by ensuring energy security of rural communities.

This review paper addresses how the use of woody debris stocks as woodfuel may offer a possible explanation to woodfuel gap, but also sets out question marks concerning crosscutting issues to rural woodfuel consumption influencing decision-making. Since woodfuel sourced from woody debris stocks does not mean the removal of living woody biomass, why should rural household-oriented woodfuel consumption be considered as a driver of deforestation? In addition, if the most fuelwood for cooking is sourced from woody debris stocks, what is the real impact of measures intended to decrease woodfuel consumption as a strategy for reducing greenhouse gases emissions? In brief, the link between rural energy security and forest ecosystems will be analyzed in this article to get a better understanding about their effects on forest carbon dynamics and their environmental implications.

\section{DYNAMICS OF WOODY DEBRIS STOCKS}

As part of the life cycle of vegetal ecosystems, living biomass becomes necromass (deadwood mostly) by either natural senescence or external factors leading to the death of their components. The dynamics of growth and death sets the performance of forest carbon pools and fluxes. Living woody biomass is transferred to death organic matter; hence, carbon content is released slowly over years or centuries (Stevens 1997, IPCC 2006, Russell et al. 2014).

Woody debris stocks play a vital role in functioning and ecological balance of forest ecosystems. They contribute to keeping productivity not only by adding significant amounts of nutrients into soil, but also by boosting water retention (Stevens 1997). Similarly, it helps to provide habitat for both animal and vegetal organisms (Stevens 1997). There is evidence that woody debris stocks improve soil stability in slopes and help to mitigate run off effects on soil loss (Stevens 1997, Paletto et al. 2012).

Carbon storage has recently emerged as one of the most important functions of deadwood because of its ability to retain $\mathrm{CO}_{2}$ for long time (Paletto et al. 2012, Russell et al. 2014). Thus, carbon dioxide released by decay can be offset by vegetation growth, thereby preventing its accumulation in the atmosphere.

Woody debris stocks of tropical forest might range from 1 to $178 \mathrm{Mg} \mathrm{ha}^{-1}$ depending on forest type and structure, as well as on human-induced disturbance degree (Palace et al. 2012, Pfeifer et al. 2015). Accumulation of deadwood may strengthen wildfires occurrence since it represents a significant fraction of fuel load in most forest types, included tropical ecosystems (Paletto et al. 2012).

\section{GATHERING OF WOODY BIOMASS FOR RURAL COOKING}

Subsistence-oriented woodfuel gathering in rural areas is a low input-demanding activity, except for the time and human power of the woodfuel collector. Both inputs mean a high opportunity cost for gatherers, thus they will spend on them as little as possible in order to allocate them to income generating activities for bringing benefits to their homes.

Cooking is a basic need that must be met on a daily basis, as well as other rural livelihood needs. Solutions are hardly found either by long-term or mid-term measures. Making a choice about certain fuel for cooking does not only depend on its availability but also its "readiness to use". For this reason, well-seasoned and easy-to-split woody biomass will be preferred by gatherers as woodfuel. Given that woodfuel sourced from woody debris stocks meets both features, there is a noticeable preference in collecting such woody biomass by users from forests or other woody formations. The rationale behind this choice is because deadwood is almost ready to use (sometimes, a few days for air-drying the remaining moisture will be needed). Instead, freshly cut wood cannot immediately be used as fuelwood because of its high moisture content that, even in some tree species, may be higher than $200 \%$ (Glass and Zelinka 2010).

On the other hand, moisture content of woody debris will vary according to decay stage (Stevens 1997, Yu et al. 2003). Yu et al. (2003) showed that under natural conditions, coarse woody debris of a coniferous forest absorbed water from surroundings by ranging between $100 \%$ for decomposition degree I (the least decayed) and $750 \%$ for decomposition degree $\mathrm{V}$ (the most decayed), respectively.

The ability of wood for losing moisture (desorption) presents remarkable differences between freshly cut wood and deadwood. In the former case, wood must lose water until equilibrium moisture content has been reached, whereas woody debris will take less time to remove the remaining water because its equilibrium point has already been reached. Even though deadwood can soak up and hold wa- 
ter due to exposure to surroundings conditions (e.g.: rain, soil moisture or runoff), this can be removed in a matter of days (Yu et al. 2003). This is the most valuable feature of woody debris to woodfuel collectors since longer airdrying times will not be required.

The hardness level of deadwood is another characteristic that is highly regarded by collectors. Woody debris of early-stage decay classes (I-II) are the most suitable for burning because their high density allows keeping a longlasting flame. Even, the observational evidence shows that wood of third decay class is more easily lit than slightly decayed one is. Deadwood belonging to this decay stage is featured by having lost between $25-50 \%$ of its mass, which means a large amount of porosity that facilitates fire spreading (Stokland et al. 2012). Furthermore, due to its structural weakness, moderately decayed woody debris can easily be chipped into small pieces, which helps starting a fire quickly.

Gathering woody biomass available on forest floor spends less time and effort than undertaking the tough task of cutting trees. Sometimes, woodfuel collectors must split downed dead logs when the burden of carrying either on back or by using draft animals proves unfeasible. Exceptionally, woodfuel gathering in developing countries still remains as a handmade task aided by some tools (e.g.: axes or "machetes").

\section{WOODY DEBRIS STOCKS AND WOODFUEL DEMAND}

Over decades, woodfuel consumption has been considered a harmful activity for the environment, mostly for forest sustainability because mainstream thinking has the wrong belief that woodfuel just might be obtained from living trees (Eckholm 1975, Spetch et al. 2015). The meaningful role of woody debris as woodfuel source has been systematically underestimated by forest statistics from mid-1970s onwards. For a long time, forest inventories were orientated to quantifying timber stocks, by overlooking other components less interesting from a profitable view, although ecologically and environmentally important (Ritter and Saborowski 2014). According to Forest Resources Assessment 2010, forest deadwood stocks were estimated at $67 \mathrm{Pg}$ by 2005 around the world, of which about $52 \%(\sim 35 \mathrm{Pg})$ came from tropical forests (FAO 2010). The worldwide woodfuel gathering in 2015 rose by 1,862 million cubic meters; being collected $71 \%$ from tropical regions (FAO 2017). This figure might account for $1.35 \mathrm{Pg}$ of woody biomass used as woodfuel, which coincides with woodfuel demand by 2009 that, according to Bailis et al. (2015), could have been about to $1.36 \mathrm{Pg}$. Both numbers just would account for almost $3.8 \%$ of woody debris stocks estimated to tropical forests by 2005 , respectively.

As living biomass, woody debris stocks keep changing, then new amounts of deadwood are yearly added because of mortality process of above and belowground forest bio- mass. By reviewing much of research literature regarding necromass productivity of tropical forests, Palace et al. (2012) found out that such parameter ranged from $0.1 \mathrm{Mg}$ $\mathrm{ha}^{-1}$ year $^{-1}$ for a young mangrove forest to $9.53 \mathrm{Mg} \mathrm{ha}^{-1}$ year ${ }^{-1}$ for a lower montane moist forest. This variability is a consequence both of the characteristics of forest and disturbance degree to which it had been subjected in the past. Based on these data, necromass productivity of forest may account for $2 \%$ of the total aboveground biomass stocks (Palace et al. 2012). This suggests that close to $12 \mathrm{Pg}$ of woody debris might be being incorporated to world forest necromass pool, from which $6.5 \mathrm{Pg}$ would be coming from tropical regions.

If global woodfuel demand for cooking and heating rises to $1.36 \mathrm{Pg}$ year $^{-1}$ (a less conservative scenario), such figure would account for one-seventh of woody necromass productivity per year in tropical regions. By taking into account this estimation and, except by certain woodfuel "hot spots", it is hardly believable that much of rural household woodfuel consumption, in developing countries, is not being supplied by woody debris stocks.

\section{COULD WOODY DEBRIS STOCKS TRY TO EXPLAIN THE “WOODFUEL GAP” THEORY?}

In mid-1970s, the thinking about an imminent midterm forest depletion because of woodfuel collection was fostered by the cataclysmic and unhopeful view of Eckholm (1975) in his influential essay "The other energy crisis: firewood". The global forest productivity was overlooked due to lack of knowledge and information mainly concerning dynamics of tropical forest ecosystems (FAO 1997). Data of forest biomass supply was generally overcome by woodfuel demand as a consequence of population growth happening in developing countries. The difference between forest ecosystems ability for providing woody biomass and projected woodfuel consumption set up a critical scenario known as the "woodfuel gap" theory (Arnold et al. 2003, Bensel 2008).

The increase of forestry knowledge basis and further detailed studies on forest structure and dynamics at regional or national levels proved tree growth data used by initial calculations underestimated those happenings in the field. For instance, Openshaw (2011) pointed out that woody biomass productivity was closely linked to water availability; subsequently it was possible to find forest ecosystems growing between $4-7 \mathrm{Mg} \mathrm{ha}^{-1}$ year $^{-1}$ depending on rainfall regime on site. Such an author indicated that these numbers surpassed those usually cited by international agencies in order to estimate potential biomass supply from forests. Most studies supporting the "woodfuel gap" theory have also excluded woody debris as woodfuel source (Openshaw 2011). As aforementioned, woody necromass productivity might range between 0.1 and $10 \mathrm{Mg} \mathrm{ha}^{-1}$ year ${ }^{-1}$, being comparable to aboveground biomass growth rate which can vary from 0.5 to $15 \mathrm{Mg} \mathrm{ha}^{-1}$ 
year ${ }^{-1}$ for temperate forests and $0.2-18 \mathrm{Mg} \mathrm{ha}^{-1}$ year $^{-1}$ for the tropical ones, respectively (IPCC 2006).

The forecasts of "woodfuel gap" were proved unrealistic when compared to field-based data and thus, has been rejected by certain circles of researchers and scholars. This theory failed to take into account basic socioeconomic issues such as adaptive ability of woodfuel users in response to shortage conditions (Dewees 1989). It was also showed that forests were not necessarily the only source for collecting woodfuel, but also other woody formations as woodlots, live fences, home gardens and some crops met such role (FAO 1997, Arnold et al. 2003, Bensel 2008,).

Moreover, woody formations other than forests also produce necromass by either natural senescence or maninduced activities (IPCC 2006). In the tropics, both coffee and cocoa crops have proved to be good examples. Shade coffee plantations can yield from 0.02 to $1.4 \mathrm{Mg} \mathrm{ha}^{-1}$ of woody debris depending on shade tree species and crop management (Soto-Pinto and Aguirre-Dávila 2015, Masuhara et al. 2015). On the other hand, woody necromass production in cocoa plantations growing along with shade trees can range between 0.02 and $12.4 \mathrm{Mg} \mathrm{ha}^{-1}$ (Wardah et al. 2011, Somarriba et al. 2013).

These plantation crops must be removed and replaced by new individuals as their yield decreases to ensure a profitable production level for farmers. For instance, the productive cycle of coffee plantations can vary from five to seven years according to farming practices and environmental conditions. A 5 - 7-year-old coffee tree might produce up to $2.8 \mathrm{~kg}$ of woody biomass (Segura et al. 2006). If a planting density of between 2,000 and 5,000 coffee trees per hectare is considered, from 5.6 to $19 \mathrm{Mg} \mathrm{ha}^{-1}$ of woody biomass coming from coffee plantations (shade trees not included) might be gathered from each turnover.

Unlike coffee, cocoa cultivation has a longer productivity cycle, whose yield starts decreasing quickly from 25 years old onwards (Mahrizal et al. 2013). According to age and density of cultivation, cocoa plantations might generate from 14 to $50.7 \mathrm{Mg} \mathrm{ha}^{-1}$ of woody biomass in each turnover time (Somarriba et al. 2013, Mohammed et al. 2015).

Crop turnover transfers a huge amount of woody debris from living aboveground biomass to dead organic matter pool, which is mostly used as fuel. The contribution of woody debris stocks from woody crops is reflected, for instance, by taking the case of Colombia. Currently, this nation is the third largest coffee producer in the world after Brazil and Vietnam (ICO 2017) and the tenth largest producer of cocoa worldwide (Anga 2014), respectively. By 2014 , this country had about 800,000 ha in coffee plantations and 160,000 ha in cocoa plantations (MADR 2017). More than $90 \%$ of total land area of both crops is located in 15 of 32 departments in which the country is administratively divided. This region has roughly eight million of inhabitants, of which $50 \%$ relies on fuelwood for cooking, accounting for a demand of $5.77 \mathrm{Tg}_{\mathrm{gear}}{ }^{-1}$. Despite forest cover accounts for $52 \%$ of its inland area, very few inventories have been carried out for assessing woody debris stocks in Colombian forests. However, preliminary studies suggest deadwood stocks would range from $2.2-80.2 \mathrm{Mg}$ $\mathrm{ha}^{-1}$ depending on the type of forest ecosystem (Navarrete et al. 2011, Restrepo et al. 2012).

When a planting density over 5,000 bushes per hectare and a 7-years productive cycle are considered, it is estimated that one coffee plantation hectare in Colombia may generate $11.6 \mathrm{Mg}$ of woody biomass incorporated to dead organic matter pool in turnover time. On the other hand, the average density of cocoa plantations is 1,200 trees per hectare and its productive cycle might be extended up to 30 years, even though it is possible to find less-productive plantations as old as 40 years and over. Woody biomassbased productivity of cocoa plantation in Colombia is as high as $66 \mathrm{Mg} \mathrm{ha}^{-1}$ at the end of the life cycle (Andrade et al. 2013).

Thereby, 9.28 and $10.56 \mathrm{Tg}$ of woody biomass from both crops would be transferred from aboveground biomass to woody debris stocks when their productive lifecycles had finished. If such figures are divided by their lifecycles (i.e.: seven years by coffee and 30 years by cocoa), then 1.32 and $0.35 \mathrm{Tg}$ of woody necromass would be yearly contributed by both crops. Total availability of woody debris coming from coffee and cocoa cultivation would be as much as $1.67 \mathrm{Tg}_{\text {year }}{ }^{-1}$, accounting for $29 \%$ of the annual fuelwood demand of four million rural people settled in that sub-national region.

Around the world, both cultivations add up more than 20 million hectares (UTZ 2016); $88 \%$ is similarly shared between Sub-Saharan Africa and Latin America, and the remaining $12 \%$ between Southeast Asia and India. Furthermore, tropical crops as tea, coconut and oil palm are also a source of woody biomass, which cover more than 31 million hectares together (UTZ 2016). The aforementioned calculations indicate that agricultural woody wastes might be meaningful contributions to woodfuel supply for the poorest rural people in tropical countries.

Unlike agricultural woody wastes, however, only a little part of forest woody debris is available for collecting since most tropical forests are either far away from human settlements or within protected areas where woodfuel gathering is not allowed. According to FAO (2010) there are close to 560 million hectares of tropical forests oriented to productive activities, accounting for $31 \%$ of the world tropical forest cover, which might generate about to $1.66 \mathrm{Pg}$ year $^{-1}$ of woody necromass. When non-forest woody formations such as agroforestry systems, which represent near 500 million hectares, are taken into account (Zomer et al. 2014), $0.41 \mathrm{Pg}_{\text {year }}{ }^{-1}$ of woody debris might be added. In addition, agricultural woody wastes would globally contribute to $0.12 \mathrm{Pg}_{\text {year }}{ }^{-1}$ as presented in table 1 . Therefore, annual available supply from woody debris stocks would be as high as $2.19 \mathrm{Pg}_{\text {year }}{ }^{-1}$, which exceeds by almost $40 \%$ both woodfuel collection data cited by FAO 
(2017) for tropical forest in the Yearbook of forest products 2015 (i.e.: 1,862 million cubic meters is roughly tantamount to $1.35 \mathrm{Pg}$ ) and the figure proposed by Bailis et al. (2015).

These estimations show how woodfuel exploitation for rural subsistence consumption is far from being a real threat to integrity of tropical forest ecosystems because mortality-based dynamics of aboveground biomass is turning woody debris into necromass stocks as fast as woodfuel collection rates. When the "woodfuel gap" theory arose in mid-1970s, the world population depending on woodfuel as the main energy source for cooking had reached 1.5 billion people while tropical forests covered 2.1 billion hectares (FAO 1982). After four decades, people consuming woodfuel doubled and the tropical forest area has decreased by about $16 \%$ (FAO 1982, Keenan et al 2015). Accordingly, a logical conclusion emerges: if deadwood from forestland and other woody formations can currently meet global woodfuel demand to three billion people, then it would make sense to think 40 years ago, woodfuel supply was only sufficient when woodfuel-demanding people were just half and the tropical forest area in developing countries was higher than it is presently. Under this viewpoint, it is understandable why forecasts about "woodfuel gap" failed to come true. The approach used to project woodfuel demand not only underestimated growth ability from tropical forest aboveground biomass (as well as tree outside the forest), but also the potential of woody debris stocks as a woodfuel source had been overlooked.

\section{IMPACTS OF WOODFUEL COLLECTION FROM WOODY DEBRIS STOCKS ON FORESTS}

The widespread belief of rural household woodfuel consumption as a deforestation driver has been a controversial subject among researchers and scholars. There is little evidence supporting such claim, instead, many studies call into questioning the link between both of them (Dewees 1989, Arnold et al. 2003, Openshaw 2011).

Agricultural expansion, both arable and pastoral, has been the main driver of forest cover depletion, thus woody debris, as by-product resulting from such process, is used as fuel. The "opportunistic" use of woody debris as woodfuel by collectors has been misunderstood as one of the causes leading forest clearance (May-Tobin 2011). Woodfuel collection from the forest does not necessarily entail that trees must be removed because naturally occurring woody necromass prevents wood cutting intended for household subsistence use.

Although woody debris as woodfuel might be playing in favor of tropical forest conservation, its role in the forest degradation process is still to be solved. The simplest manner to define forest degradation is "the reduction of capacity of a forest to provide good and services" (FAO 2011). However, from view of carbon fluxes, it is termed as "A direct human-induced long term loss (persisting $\mathrm{X}$ years or more) of at least Y\% of forest carbon stocks (and forest values) since time $\mathrm{T}$ and not qualifying as deforestation" (IPCC 2003). A few studies have assessed how the depletion of dead organic matter as carbon pool may be contributing to forest degradation. For instance, García-Oliva et al. (2014) compared carbon contents of four fragmented forest types according to the woodfuel exploitation level. As expected, less disturbed forest characterized by both higher tree density and larger basal area, showed the highest carbon content $\left(670 \mathrm{Mg} \mathrm{ha}^{-1}\right)$. In contrast, the carbon content of disturbed forest was as low as $55 \%$ compared to less disturbed forest ( $\left.303 \mathrm{Mg} \mathrm{ha}^{-1}\right)$. Nevertheless, deadwood was not included in this survey, thus making conclusions to determine how woody debris stocks may be affected by woodfuel collection proved to be difficult,

Table 1. Annual woody wastes production from tropical crops.

Producción anual de residuos leñosos procedentes de cultivos tropicales.

\begin{tabular}{lccc}
\hline Crop & $\begin{array}{c}\text { World area } \\
\text { (million hectares) }\end{array}$ & $\begin{array}{c}\text { Average woody wastes productivity } \\
\left(\mathrm{Mg} \mathrm{ha}^{-1} \text { year }^{-1}\right)\end{array}$ & $\begin{array}{c}\text { Woody wastes production } \\
\left(\text { Pg year }^{-1}\right)\end{array}$ \\
\hline Coffee & 10.1 & $1.65^{\mathrm{a}}$ & 0.016 \\
Cocoa & 10.0 & $2^{\mathrm{b}}$ & 0.02 \\
Tea & 3.5 & $0.7^{\mathrm{c}}$ & 0.002 \\
Oil palm & 17.0 & $3.3^{\mathrm{d}}$ & 0.056 \\
Coconut & 11.1 & $3^{\mathrm{e}}$ & 0.033 \\
Total & 51.7 & - & 0.127 \\
\hline
\end{tabular}

a. Based on Segura et al.'s data (2006) and supposing a density of 5,000 bushes per hectare and 7-years productive lifespan.

b. Sourced from Andrade et al. (2013).

c. Based on Subramaniyan et al. (2017) and supposing a density of 2,500 bushes per hectare and 60-years productive lifespan.

d. Based on Abdullah and Sulaiman's data (2013).

e. Sourced from Ranasinghe and Thimothias (2012). 
even more so, if such activity is either really driving forest degradation or it is a result of another form of forest exploitation.

If, from a carbon storage perspective, forest degradation is thought as on-going loss of such pool; then, the use of woody necromass as fuel might be as degrading as other practices contributing to forest cover depletion. Due to decay of organic matter, the carbon content of deadwood is released to the atmosphere as carbon dioxide. Nevertheless, this process takes place slowly and gradually, unlike combustion, in which carbon dioxide is released straight away. Russell et al. (2014) estimated residence times of coarse woody debris by 80 years for conifers and 69 years for hardwoods in eastern temperate forests of USA, by modelling decay process. Outputs generated by such modelling show coarse woody debris loses its mass exponentially (negative), indicating a faster decay rate at early years and slower as time passes, which is reflected in its half-life time (Russell et al. 2014). In tropical ecosystems, factors such as humidity and temperature have an influence over decay rate of organic matter, hence it is foreseeable both half-life and residence time to be as far less as pointed out by Russell et al. (2014). Gurdak et al. (2013) seem to bear out this idea in assessing dynamics of coarse woody debris along elevation gradient in Peruvian highland tropical forest where residence times were considerably lower, ranging from 2.9 to 6.8 years for hardwoods. Whether the proportion biomass remaining model proposed by Russel et al. (2014) can forecast how coarse woody debris decreases through time due to decay, then an inversely proportional pattern of carbon loss of coarse woody debris will be displayed (i.e.: a logarithmic model).

The aforementioned significantly affects both the manner and amount of carbon fluxes that are released to the atmosphere. If it is assumed that in steady-state forest ecosystem, these carbon fluxes are kept equal, then the mortality is offset by biomass growth (Gurdak et al. 2013). Once carbon has been transferred to necromass, however, it might be released in a shorter time because of the combustion when woodfuel burns due to wildfires or man-induced activities. If a demand of one ton per year of woodfuel is considered through 20 year, then 20 tons will be used by the end. Such woody biomass might take two alternative paths in order to release its carbon content: either via combustion or via decay. For simulating decay emissions, biomass loss should be modelled using the negative exponential model as suggested by Olson (1963) and Russell et al. (2014):

$$
\text { Mass }_{t}=\text { Mass }_{0} e^{-k t}
$$

Where Mass $s_{t}$ is woody necromass at time $t$; Mass is the initial woody necromass; $k$ is the annual decay rate and $t$ is the time of reference in years.

From this equation, it is possible to find the annual decay rate $(k)$ if initial necromass, final necromass and time are known. By taking as reference the research of Russell et al. (2014), who has estimated an 8-year halflife for hardwoods belonging to climate regimes, where mean annual temperature is higher than or equal to $13.7^{\circ} \mathrm{C}$ (such as those found in tropical highlands as well) and assuming a 1-ton initial mass, it would roughly decrease by half $(0.5 \mathrm{Mg})$ when half-life has been reached, then the value of decay rate parameter $\mathrm{k}$ of 0.086 is found. In the table 2 , the percentage of remaining woody necromass for

Table 2. Simulated depletion of $20 \mathrm{Mg}$ woody necromass stock via combustion - decay paths and $\mathrm{CO}_{2}$ emissions projected.

Disminución simulada de una pila de necromasa leñosa de $20 \mathrm{Mg}$ a través de las rutas de combustión y descomposición y emisiones de $\mathrm{CO}_{2}$ proyectadas.

\begin{tabular}{cccccc}
\hline Year & PBR & $\begin{array}{c}\mathrm{PBR}_{20 \mathrm{t}} \\
(\mathrm{Mg})\end{array}$ & $\begin{array}{c}\mathrm{PBR}_{20 \mathrm{t}}+\mathrm{fw} \\
(\mathrm{Mg})\end{array}$ & $\begin{array}{c}\mathrm{E}_{\mathrm{PBR}_{200}} \\
\left(\mathrm{MgCO}_{2}\right)\end{array}$ & $\begin{array}{c}\mathrm{E}_{\mathrm{PBR}_{2-20} \mathrm{ffw}} \\
\left(\mathrm{MgCO}_{2}\right)\end{array}$ \\
\hline 1 & 0.92 & 18.35 & 17.35 & 3.02 & 4.85 \\
2 & 0.84 & 16.84 & 13.61 & 5.78 & 11.69 \\
3 & 0.77 & 15.45 & 9.51 & 8.32 & 19.19 \\
4 & 0.71 & 14.18 & 5.75 & 10.65 & 26.09 \\
5 & 0.65 & 13.01 & 2.74 & 12.79 & 31.59 \\
6 & 0.60 & 11.94 & 0.63 & 14.75 & 35.44 \\
7 & 0.55 & 10.95 & - & 16.55 & - \\
8 & 0.50 & 10.05 & - & 18.21 & - \\
9 & 0.46 & 9.22 & - & 19.72 & - \\
10 & 0.42 & 8.46 & - & 21.11 & - \\
11 & 0.39 & 7.77 & - & 22.39 & - \\
12 & 0.36 & 7.13 & - & 23.56 & - \\
13 & 0.33 & 6.54 & - & 24.63 & - \\
14 & 0.30 & 6.00 & - & 25.62 & - \\
15 & 0.28 & 5.51 & - & 26.53 & - \\
16 & 0.25 & 5.05 & - & 27.36 & - \\
17 & 0.23 & 4.64 & - & 28.12 & - \\
18 & 0.21 & 4.25 & - & 28.82 & - \\
19 & 0.20 & 3.90 & - & 29.46 & - \\
20 & 0.18 & 3.58 & - & 30.05 & - \\
\hline & & & & &
\end{tabular}

PBR: Proportion biomass remaining (\%).

$\mathrm{PBR}_{20 \mathrm{t}}$ : Proportion biomass remaining for a $20-\mathrm{Mg}$ woody debris pile following only the decay path (tons).

$\mathrm{PBR}_{20 \mathrm{t}}+\mathrm{fw}$ : Proportion biomass remaining for a $20-\mathrm{Mg}$ woody debris pile following a blended combustion-decay path (tons).

$\mathrm{E}_{\mathrm{PBR} 20 \mathrm{t}}$ : $\mathrm{CO}_{2}$ emissions by decay from $20-\mathrm{Mg}$ woody debris pile (tons).

$\mathrm{E}_{\mathrm{PBR} 20 \mathrm{t}+\mathrm{fw}}: \mathrm{CO}_{2}$ emissions by a blended combustion-decay path from $20-\mathrm{Mg}$ woody debris pile (tons). 
a decaying piece of woodfuel during a 20 -years period can be observed, moreover, how this gradual loss would occur over a 20 -tons stock. After 20 years, such woody necromass stock will have theoretically decreased to $3.5 \mathrm{Mg}$. However, when blended woodfuel decay-combustion path is taken into account, woodfuel would just deplete in six years if a collection rate of $1 \mathrm{Mg}$ year $^{-1}$ is considered.

Two additional cycles of blended decay-combustion path will be needed for meeting $1 \mathrm{Mg}$ year $^{-1}$ annual demand through 20 years. Therefore, the amount of woodfuel required would triple as well as $\mathrm{CO}_{2}$ emissions. The cumulative emissions brought about by both processes are different because the single combustion path displays a linear growth given that a similar amount of woodfuel is burnt every year while emissions from decay of woody biomass rise logarithmically as shown in figure 1 .

After 20 years, cumulative emissions from woodfuel combustion would increase close to $120 \mathrm{MgCO}_{2}$, whereas through the decay path it would just account for one quarter for the same time. The difference between cumulative emissions from combustion and decay are those emissions that will be released in advance when woody biomass burns, otherwise it would be kept in the necromass pool up to when the wood has fully decayed.

A key question arises: What is the effect of anticipated $\mathrm{CO}_{2}$ emissions from burning of coarse woody debris over atmospheric concentrations of greenhouse gases if biomass loss will be theoretically offset by regrowth? As far as it is known, deadwood used as woodfuel does not seem to have a relevant effect over such concentrations as long as the steady-state is kept. Nevertheless, ongoing depletion of forest cover sets out a paradoxical situation where

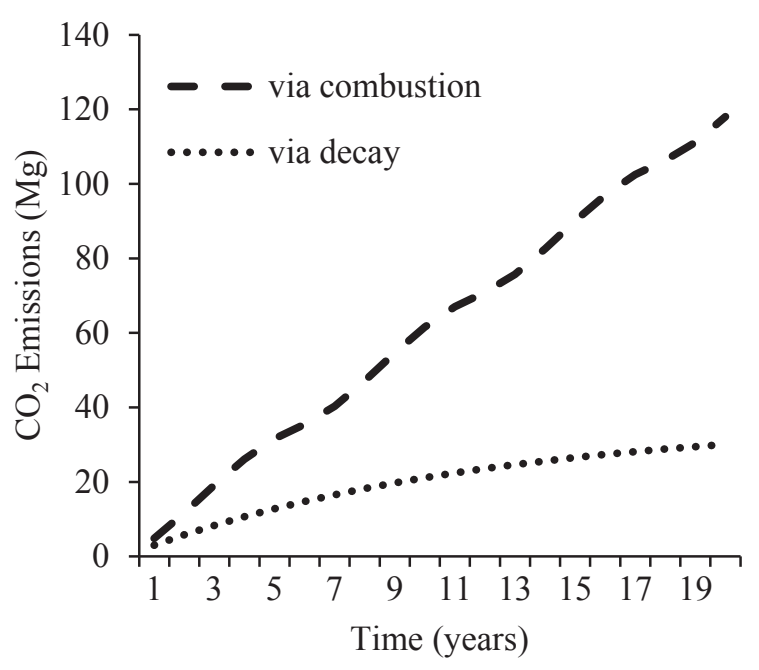

Figure 1. Cumulative $\mathrm{CO}_{2}$ emissions from combustion and decay scenarios for $20 \mathrm{Mg}$ woody necromass stock.

Emisiones acumuladas de $\mathrm{CO}_{2}$ de los escenarios de combustión y descomposición para una pila de necromasa leñosa de $20 \mathrm{Mg}$. woodfuel collection, far from being a deforestation driver, might be affected by deforestation itself. If living biomass stocks were removed, necromass stocks would also exhaust, thus carbon fluxes between both pools will disrupt. As forest cover depletes, availability of woody necromass oriented to woodfuel use will also decrease bringing about serious consequences for energy supply of rural communities (in certain cases, the urban ones as well) relying on it for meeting their cooking and heating needs.

\section{POLICY IMPLICATIONS OF WOODY DEBRIS STOCKS USE AS WOODFUEL}

How the renewability of biomass is affected by woody debris collection inside a specific region is a matter that has yet to be solved. This is a key issue for climate mitigation measures approaching woodfuel consumption reduction (i.e.: improved cookstoves). The use of woody biomass as woodfuel increases greenhouse gases emissions (mainly $\mathrm{CO}_{2}$ ) if the amount collected surpasses regrowth in such an area. The difference between both of them is known as the fraction of non-renewable biomass, which has been put in question because of uncertainty related to variability in the results reached when different methodological approaches are run (Lee et al. 2013).

When included, woody debris stocks will increase the demonstrably renewable biomass bringing about the opposite effect on the non-renewable biomass. As the nonrenewable biomass values decrease, the fraction of nonrenewable biomass will do too. In other words, an increase of woody debris stocks positively affects the availability of demonstrably renewable biomass at the expense of a lower value of the fraction of non-renewable biomass.

A short review of literature about this topic shows at least two quantitative procedures for calculating the fraction of non-renewable biomass (Lee et al. 2013). They agree on using aboveground biomass stocks and their productivity as parameters to allow determining the nonrenewable biomass, nonetheless excluding woody debris stocks as additional factor might alter the fraction of non-renewable biomass calculations. Perhaps, the most comprehensive methodological approach to calculate the fraction of non-renewable biomass is displayed by EB 67 report, annex 22 of Clean Development Mechanism. In it, default values are defined for least developed countries and small island developing states from a step-by-step procedure through which the fraction of non-renewable biomass arises from dividing the non-renewable biomass by the demonstrably renewable biomass (CDM - Executive Board 2012). This latter comes from multiplying the protected area extent of forest by the annual growth rate of biomass.

By coincidence, Bailis et al. (2015) have found that the fraction of non-renewable biomass for pan-tropical areas ranging from $27-34 \%$, which are lower than those used by carbon markets-oriented, improved cookstoves projects worldwide (e.g.: UNFCCC default values for least 
developed countries and small island developing states). However, these figures arise from improved data of aboveground biomass stocks estimations based on both GIS assessments and field surveys in which, deadwood pools were presumably left out, thus, those numbers could be even lower.

It should be noted that the demonstrably renewable biomass not only originated from forest lands but also from other types of vegetation cover which might provide renewable biomass sourced from dead wood, dung and agricultural residues.

The decrease of the non-renewable biomass fraction has an impact over policies oriented to reduce woodfuel consumption from the supply-side, which is directly related to climate change. For instance, climate benefits of improved cookstoves projects coming from savings of unsustainably harvested woodfuel that contributes to $\mathrm{CO}_{2}$ emissions. If the non-renewable biomass were meaningfully lower than widely believed, then, impact of improved cookstoves dissemination would be lower than expected (Bailis et al. 2015). Thus, another question arises: Can woodfuel collection really be labelled as unsustainable even if it is sourced from woody debris stocks in places where its production might be exceeding demand for such resource? If compared to less conservative estimations of woodfuel consumption for cooking, woody debris stocks are as much as sevenfold, therefore there are no reasons for thinking aboveground woody biomass is being depleted due to this activity. Accordingly, a most comprehensive revision of the fraction of non-renewable biomass as an indicator of woody biomass availability is needed in projects intending to assess the impact of woodfuel consumption on $\mathrm{CO}_{2}$ emissions and its repercussion on climate change.

Another poorly evaluated issue is how the collection of woody debris as cooking fuel might be playing a role as an unintended measure for preventing wildfires. Because most woody debris has low moisture content, such condition makes it prone to ignition by either naturally occurring or human-induced factors, which is risky for several forest ecosystems where fire can rapidly spread (Stephens et al. 2012). In temperate forests, fuel load reduction has become a priority as strategy of fire prevention. Such reduction focuses mostly on removing woody debris from which, only a small share is collected in order not to disturb ecological functions that are provided by woody debris into forest ecosystems (Stephens et al. 2012).

Woodfuel collection contributes to reducing fuel load of forests that might be preventing wildfires recurrence on highly vulnerable forest ecosystems, particularly when extreme climatic events arise. For instance, droughts originated by El Niño Southern Oscillation were responsible for devastation of several million hectares of tropical forest caused by wildfires between 1997 and 1998 (Siegert et al. 2001). Nonetheless, the real impact of woodfuel collection for cooking as measure for preventing wildfires can hardly be determined unless future research to be carried out on this topic to provide evidence about this claim. FINAL REMARKS

This article purports to show how woody debris has played a key role as a woodfuel source for most of the world population that relies on traditional fuels. Unlike mainstream viewpoints, it seems improbable that woodfuel consumption oriented to rural cooking has any incidence on the deforestation processes of tropical forests. This is because woodfuel collected comes from necromass stocks of forests, which are roughly estimated to be $35 \mathrm{Pg}$, enough to meet global annual demand representing 3.8 \% of this figure. If only the annual woody necromass productivity were considered (it has been estimated by $9.5 \mathrm{Pg}$ year ${ }^{-1}$ ), then, the globaldemand wouldjustaccount for $14.3 \%$ of this latter one, showing that supply displays values higher than demand does. These numbers contradict the ideas about negative balances regarding woodfuel availability. In addition to woody debris from forestlands, other land uses categories could also contribute to woody debris stocks (e.g.: other woodlands, croplands and so-called "trees outside of the forest"), by adding together $0.53 \mathrm{Pg}$ year ${ }^{-1}$, which represents nearly two-fifth in regard to the global demand.

If woodfuel is widely found on forest floor, it is unlikely that collectors must cut down trees for ensuring their own supply; consequently, the link between deforestation and woodfuel use is unclear. Conversely, forest degradation sets out a different viewpoint. Based on the IPCC definition about forest degradation, woody debris stocks are meaningfully depleted by woodfuel collection, which would shorten carbon residence time as compared to woody debris decay modelling as proposed by Russel et al. (2014). Thereby, the usage of woody debris as woodfuel is increasingly accelerating carbon fluxes from necromass pool to atmosphere with regard to reference scenario (decay).

There is uncertainty about how early loss of carbon is being offset by forest growth rates because tropical forest productivity has wide variations ranging from $0.2-18 \mathrm{Mg}$ $\mathrm{ha}^{-1}$ year $^{-1}$ according to type of ecosystem and climatic zone (IPCC 2006). If compared to living biomass stocks, the productivity of tropical forest might account for under $1 \%$ up to $3.7 \%$, which, for practical purposes, are similar to woody debris production rate from mortality (i.e.: $2 \%$ of aboveground biomass stocks), stating that aboveground biomass sequesters similar amounts of carbon that are transferred to dead wood pools. However, woodfuel consumption might alter such balances as collection rates exceeds growth rates, although in this case, woody biomass is sourced from dead wood stocks instead of living biomass stocks. Tropical forest ecosystems, such as those found in dry zones or highland areas where net primary productivity is lower than that presented by ecosystems located in moist zones, may be particularly vulnerable to woodfuel gathering, especially if they overlap with rural settlements. In such places, woodfuel consumption per capita as high 
as $1 \mathrm{Mg}$ year ${ }^{-1}$ may be troublesome both in the mid- and long-term ranges when collection rates will have depleted woody debris stocks of those forests. Nevertheless, woodfuel sourced from woodlands other than forestlands (i.e.: agroforestry systems, woodlots or woody wastes from croplands) is likely to offset this gap and even, replace a share of woodfuel supply provided by forestlands. Therefore, more comprehensive studies about carbon fluxes dynamics inside forests and about the impacts of wood-fuel collection on carbon stored in forests must be undertaken where several woodfuel sources coexist.

A higher uncertainty is observed on real impacts of measures oriented to reducing woodfuel consumption as strategy for halting global warming such as adoption of fuelwood-savings cookstoves, which is a well-known strategy generating positive impacts on both the well-being of rural communities and the environment. Emissions from woodfuel combustion might contribute to the increase of greenhouse gases concentrations if harvested unsustainably, which is an issue of concern to climate change.

To take the renewability status of biomass for granted, carbon losses and gains must be balanced, that is, the amount of carbon dioxide released must be as high as that sequestered by regrowth. Since the contribution of improved cookstoves projects is based on decreasing woodfuel consumption coming from the fraction of non-renewable biomass, it is likely that the impact on decreases in $\mathrm{CO}_{2}$ will be lower than expected because as woody necromass pools are included into the accounting of renewable biomass, the fraction of non-renewable biomass will assume lower values than those considered by several cookstoves projects nowadays. This is consistent with findings reported by Bailis et al. (2015). Thus, the attractiveness of carbon market-oriented cookstoves projects may decline because their profitability and sustainability depend on selling carbon credits regarding volume of reduced emissions. While the effect brought about by early $\mathrm{CO}_{2}$ emissions from woodfuel combustion over greenhouse gases concentrations in the atmosphere remains unclear, the role of woodfuel-savings cookstoves as a measure for slowing down the release of $\mathrm{CO}_{2}$ should be stood out.

Because of its environmental implications, the role of woodfuel collection sourced from forest woody debris as a strategy for preventing wildfires should be comprehensively assessed in regions where fuel loads are high and prone to ignition. Likewise, the use of geographical information systems (GIS) may turn into a key tool to identify overlaps between woodfuel consumption "hotspots" (e.g.: Woodfuel Integrated Supply/Demand Overview Mapping methodology - WISDOM) and areas with low wildfire occurrence (e.g.: Along Track Scanning Radiometer - ATSR World Fire Atlas) aiming at ascertaining statistical correlations between both events. More site-specific analyses will be required to validate this claim.

Household woodfuel consumption sourced from woody debris stocks does not seem to support the idea linking it to tropical deforestation however, ironically, deforestation may become a threat to energy security of rural communities relying on forests as main source of fuel for cooking. It is possible that loss of forest cover jeopardize the permanent production of woody debris because of the proportionality and dependence existing between them. Clearly, the removal of living woody biomass will produce huge amounts of woody debris because of either forest clearance or land-use changes. Nonetheless, once that happens, the cycle is disrupted definitively. In this sense, woodfuel collection must not be seen as a deforestation driver, rather as a livelihood activity vulnerable to its consequences.

Finally, ecological functions inherent to tropical forest other than providing woodfuel should not be ignored. Instead, sound forest management strategies should be encouraged to strike a balance between sustainability of forest ecosystems and the well-being of rural communities relying on them.

\section{ACKNOWLEDGMENTS}

The author wishes to express his gratitude to all staff of Fundación Natura for their worthy support during the writing of this paper. Likewise, the author also expresses his gratitude to the anonymous reviewers whose inputs and comments were very useful, thus they helped to improve this article.

\section{REFERENCES}

Abdullah N, F Sulaiman. 2013. The oil palm wastes in Malaysia. In Matovic MD eds. Biomass now - sustainable growth and use. Rijeka, Croatia. InTech. p. 75-100. DOI: $10.5772 / 55302$

Andrade HJ, JM Figueroa, D Silva. 2013. Almacenamiento de carbono en cacaotales (Theobroma cacao) en ArmeroGuayabal (Tolima, Colombia). Scientia Agroalimentaria 1: 6-10.

Anga J. 2014. The world cocoa economy: current status, challenges and prospects. Consulted Apr. 1, 2017. Available in http://unctad.org/meetings/es/Presentation/SUC_ MEM2014_09042014_ICCO.pdf

Arnold M, G Köhlin, R Persson, G Shepherd. 2003. Woodfuel revisited: what has changed in the last decade? Bogor, Indonesia. Center for International Forestry Research. 35 p.

Bailis R, R Drigo, A Ghilardi, O Masera. 2015. The carbon footprint of traditional woodfuels. Nature Climate Change 5: 266-272. DOI: 10.1038/MCLIMATE2491

Bensel T. 2008. Fuelwood, deforestation and land degradation: 10 years of evidence from Cebu province, the Philippines. Land Degradation \& Development 19(6): 587-605. DOI:10.1002/ldr.862

CDM - Executive Board (Clean Development Mechanism). 2012. Information note: default values of fraction of nonrenewable biomass for least developed countries and small island developing states. Consulted Jun. 15, 2017. Available in https://cdm.unfccc.int/filestorage/H/2/9/H29X6EKQMJU7RY85DIT4ZPFAL3O1GW/eb67_repan22.pdf?t 
$=$ TDV8b3JuYXJufDChm31BvAYaTQmHxEq-uqMu

Dewees P. 1989. The woodfuel crisis reconsidered: observations on the dynamics of abundance and scarcity. World Development 17(8): 1159-1172.

Eckholm E. 1975. The other energy crisis: firewood. Washington D.C, United States. Worldwatch Institute. 22 p.

FAO (Food and Agriculture Organization of the United Nations, IT). 1982. Tropical forests resources. Rome, Italy. FAO. 106 p. $\left(\right.$ Paper $\left.n^{\circ} 30\right)$

FAO (Food and Agriculture Organization of the United Nations, IT). 1997. Regional study on wood energy today and tomorrow in Asia. Bangkok, Thailand. FAO-RWEDP. 168 p. (Fild Document $\mathrm{n}^{\circ} 50$ )

FAO (Food and Agriculture Organization of the United Nations, IT). 2010. Global forest resources assessment 2010, main report. Rome, Italy. FAO. 340 p. (Forestry paper 163).

FAO (Food and Agriculture Organization of the United Nations, IT). 2011. Assessing forest degradation. Towards the development of globally applicable guidelines. Rome, Italy. FAO. 99 p.

FAO (Food and Agriculture Organization of the United Nations, IT). 2017. Yearbook of forest products 2015. Rome, Italy. FAO. 243 p.

García-Oliva F, S Covaleda, J Gallardo, C Prat, R VelásquezDurán, J Etchevers. 2014. Firewood extraction affects carbon pools and nutrients in remnant fragments of temperate forests at the Mexican Transvolcanic Belt. Bosque 35 (3): 311-324. DOI:10.4067/S0717-92002014000300006.

Glass SV, SL Zelinka. 2010. Moisture relations and physical properties of wood. In U.S. Department of Agriculture eds. Wood handbook - wood as an engineering material. Madison, United States. Centennial Edition. p (4)1 - (4)19.

Gurdak D, L Aragão, A Rozas-Dávila, W Huasco, K Cabrera, C Doughty, W Farfan-Ríos, J Silva-Espejo, D Metcalfe, M Silman, Y Mahli. 2013. Assessing above-ground woody debris dynamics along a gradient of elevation in Amazonian cloud forest in Peru: balancing above-ground inputs and respiration outputs. Plant Ecology \& Diversity 7 (1-2): 143-160. DOI: 10.1080/17550874.2013.818073

ICO (International Coffee Organization, UK). 2017. Total production by all exporting countries. Updated, January 2017. Viewed April 1, 2017. Available in http://www.ico.org/prices/po-production.pdf

IPCC (Intergovernmental Panel on Climate Change, CH). 2003. Definitions and methodological options to inventory emissions from direct human induced degradations of forests and devegetation of other vegetation types. Hayama, Japan. IPCC-IGES. 32 p.

IPCC (Intergovernmental Panel on Climate Change, CH). 2006. Volume 4: agriculture, forestry and other land use. In Eggleston S, L Buendía, K Miwa, T Ngara, K Tanabe eds. IPCC guidelines for national greenhouse gas inventories. Hayama, Japan. IPCC - IGES. p (1)1 - (12)33.

Keenan R, G Reams, F Achard, J V de Freitas, A Grainger, E Lindquist. 2015. Dynamics of global forest area: results from the FAO global forest resources assessment 2015. Forest Ecology and Management 353: 9 - 20. DOI: 10.1016/j.foreco.2015.06.014

Lee C, C Chandler, M Lazarus, F Johnson. 2013. Assessing the climate impacts of cookstoves projects. Issue in emissions accounting. Stockholm, Sweden. Stockholm Environment
Institute. $25 \mathrm{p}$.

Mahrizal, L Lanier Nalley, B Dixon, J Popp. 2013. An optimal phased replanting approach for cocoa trees with application to Ghana. Agricultural Economics 45(3): 291-302. DOI: 10.1111/agec. 12065

Masuhara A, E Valdés, J Pérez, D Gutiérrez, J Cutberto Vásquez, E Salcedo, M Juárez, A Merino. 2015. Carbono almacenado en diferentes sistemas agroforestales de café en Huatusco, Veracruz, México. Revista Amazónica Ciencia y Tecnología 4(1): 66-93.

May-Tobin C. 2011. Wood for fuel. In Boucher D, P Elias, K Lininger, C May-Tobin, S Roquemore, E Saxon eds. The root of the problem: what's driving tropical deforestation today? Cambridge, United States. Union of concerned scientists. p. $79-87$.

MADR (Ministerio de Agricultura y Desarrollo Rural, Colombia). 2017. Estadisticas agrícola. Updated, May 2016. Consulted Apr. 1, 2017. Available en http://www.agronet.gov. co/estadistica/Paginas/default.aspx

Mohammed A, J Robinson, D Midmore, A Verhoef. 2015. Biomass stocks in ghanaian cocoa ecosystems: the effects of the region, management and stand age of cocoa trees. European Journal of Agriculture and Forestry Research 3(2): 22- 43.

Navarrete D, A Duque, A Yepes, J Phillips, K Cabrera, E López, C Rivera, M García, M Ordoñez. 2011. Madera muerta: un reservorio de carbono en bosques naturales de Colombia. Validación metodológica para su medición en el marco de proyectos REDD+. Bogotá D.C, Colombia. Instituto de Hidrología, Meteorología y Estudios Ambientales - IDEAM. $29 \mathrm{p}$.

Olson J. 1963. Energy storage and the balance of producers and decomposers in ecological systems. Ecology 44(2): 322331.

Openshaw K. 2011. Supply of woody biomass, especially in the tropics: is demand outstripping sustainable supply? International Forestry Review 13(4): 487-499. DOI: 10.1505/146554811798811317

Palace M, M Keller, G Hurtt, S Frolking. 2012. A review of above ground necromass in tropical forests. In Sudarshana $\mathrm{P}$, M Nageswara-Rao, J Soneji eds. Tropical forests. Rijeka, Croatia. InTech. p. 215 - 252. DOI: 10.5772/33085

Paletto A, F Ferretti, I De Meo, P Cantiani, M Focacci. 2012. Ecological and environmental role of deadwood in managed and unmanaged forests. In Garcia J, J Diez eds. Sustainable forest management - current research. Rijeka, Croatia. InTech. p. 219 - 238. DOI: 10.5772/24894

Pfeifer M, V Lefebvre, E Turner, J Cusack, M Khoo, V Chey, M Peni, R Ewers. 2015. Deadwood biomass: an underestimated carbon stock in degraded tropical forests? Environmental Research Letters 10(4): 1-12. DOI: 10.1088/17489326/10/4/044019

Ranasinghe C, K Thimothias. 2012. Estimation of carbon sequestration potential in coconut plantations under different agro-ecological regions and land suitability classes. Journal of the National Science Foundation of Sri Lanka 40(1): 77-93.

Restrepo H, S Orrego, O Galeano. 2012. Estructura de bosques secundarios y rastrojos montano bajos del norte de Antioquia, Colombia. Colombia Forestal. 15(2): 173-189.

Ritter T, J Saborowski. 2014. Efficient integration of a deadwood 
inventory into an existing forest inventory carried out as two-phase sampling for stratification. Forestry. 87(4): 571581. DOI: $10.1093 /$ forestry/cpu016

Russell M, C Woodall, S Fraver, A D'amato, G Domke, K Skog. 2014. Residences times and decay rates of downed woody debris biomass/carbon in eastern US forests. Ecosystems. 17(5): 765-777. DOI: 10.1007/s10021-014-9757-5

Segura M, M Kanninen, D Suárez. 2006. Allometric models for estimating aboveground biomass of shade trees and coffee bushes grown together. Agroforestry Systems 68(2): 143150. DOI: $10.1007 / \mathrm{s} 10457-006-9005-x$.

Siegert F, G Ruecker, A Hinrichs, A Hoffmann. 2001. Increased damage from fires in logged forests during droughts caused by El Niño. Nature. 414: 437-440. DOI: 10.1038/35106547

Somarriba E, R Cerda, L Orozco, M Cifuentes, H Davila, T Espin, H Mavisoy, G Avila, E Alvarado, V Poveda, C Astorga, E Say, O Deheuvels. 2013. Carbon stocks and cocoa yields in agroforestry systems of Central America. Agriculture, Ecosystems and Environment. 174: 46-57. DOI: 10.1016/j. agee.2013.04.013

Soto-Pinto L, C Aguirre-Dávila. 2015. Carbon stocks in organic coffee systems in Chiapas, Mexico. Journal of Agricultural Science. 7(1): 117-128. DOI: 10.5539/jas.v7n1p117

Spetch M, S Ribeiro Pinto, U Albuquerque, M Tabarelli, F Melo. 2015. Burning biodiversity: fuelwood harvesting causes forest degradation in human-dominated tropical landscapes. Global Ecology and Conservation. 3: 200-209. DOI: 10.1016/j.gecco.2014.12.002

Stephens S, J McIver, R Boerner, C Fettig, J Fontaine, B Hartsough, P Kennedy, D Schwilk. 2012. The effects of forest fuel-reduction treatments in the United States. Bios- cience 62(6): 549-560. DOI: 10.1525/bio.2012.62.6.6

Stevens V. 1997. The ecological role of coarse woody debris. An overview of the ecological importance of CWD in BC forests. Victoria, Canada. Ministry of forest research program, British Columbia. 26 p. (Working paper 30)

Stokland J, J Sitonen, B Gunnar Jonsson. 2012. Biodiversity in deadwood. Cambridge, United Kingdom. Cambridge university press. $521 \mathrm{p}$.

Subramaniyan P, L Jevee Jothi, N Shoba, S Murugesan. 2017. Carbon sequestration in plantation crops. International Journal of Scientific Development and Research 2(5): 95101.

UTZ. 2016. UTZ impact report- March 2016. UTZ Impact report, March 2016. Combining insights from UTZ monitoring data with findings from impact studies. Amsterdam, The Netherlands. UTZ. 40 p.

Wardah, B Toknok, Zulkhaidah. 2011. Carbon stock of agroforestry systems at adjacent buffer zone of Lore Lindu national park, Central Sulawesi. Jurnal Tanah Tropika 16(2): 123-128. DOI: $10.5400 /$ jts.2011.16.2.123

Yu X, L Chen, J Niu, Y Zhao. 2003. Hidrological effects of coarse woody debris (CWD) in the sub-alpine dark coniferous ecosystem of the upper reaches of the Yangtze river (XII World forestry congress). Consulted Mar. 12, 2017. Available in http://www.fao.org/docrep/ARTICLE/WFC/ XII/0874-B1.HTM

Zomer R, A Trabucco, R Coe, F Place, M van Noordwijk, J $\mathrm{Xu}$. 2014. Trees on farm: an updated and reanalysis of agroforestry's global extent and socio-economical characteristics. Nairobi, Kenya. World Agroforestry Centre. 33 p. (Working Paper 179). 
